\title{
Improving Students' English Proficiency at Faculty of Medicine: Recommendations
}

\author{
I Made Sujana ${ }^{1}$, Untung Waluyo ${ }^{2}$, Eka Fitriana ${ }^{3}$, Dewi Suryani ${ }^{4}$ \\ \{madesujana@unram.ac.id, uwaluyo@gmail.com², e.fitria@gmail.com ${ }^{3}$ \\ Faculty of Education, the University of Mataram ${ }^{1,2,3}$
}

\begin{abstract}
From a longitudinal study on English needs analysis for students of the Faculty of Medicine, the University of Mataram, Lombok, Indonesia, it was found that there was a big gap between the target needs and the present situation of learning English. The high demand for English does not correspond to the current teaching and learning situations. This article aims to provide recommendations for the improvement of students' English proficiency at the Faculty. The data for recommendations were taken from the analysis from previous studies involving students, lecturers, documents (SKDI/Competency Standards of Indonesian Medical Doctors, the Profile of Faculty of Medicine). From the analysis of all documents, it is recommended that the Faculty (1) reconsider the policy of teaching English from a block system to a semester system to provide more input; (2) apply CLIL (content and language integrated learning) model by involving subject specialists in the block system; (3) provide online learning or online clinic for English consultation to facilitate students on their self-access language learning (SALL); (4) give exemptions to students with high scores on English proficiency tests (TOEFL, IELTS, or other recognized English proficiency tests).
\end{abstract}

Keywords: English for medicine, recommendation, CLIL, online clinics, exemption.

\section{$1 \quad$ Introduction}

For students of medicine, English plays important role from the beginning of their study. English is urgently needed for reading academic textbooks and journal articles assigned in the courses they take. Inadequate acquisition of English will cause trouble during their study. Likewise, having a good command of English will accelerate their study by accessing first-hand textbooks and journal articles and will determine their success in both academic and occupation [1]; [2]; [3].

From the longitudinal study conducted at the Faculty of Medicine, the University of Mataram Lombok from 2018-2020), it was found that the students' high demand of English at this Faculty does not match with the efforts made to the improvement of English proficiency institutionally. English has strong positions to the success of their study due to the high intensity of using it for academic reading and the fulfillment of a graduation requirement [4]. 
This paper focuses on the recommendations for English proficiency improvement for students of the Faculty of Medicine, University of Mataram, Lombok, Indonesia by considering the gap between the target needs (TSA) and the present situation analysis (PSA).

\section{Methodology}

This longitudinal study employs descriptive research, initiated by conducting needs analysis, designing, curriculum and syllabus for language programs for students of medicine, developing learning materials based on the syllabi. The data were taken from students of medicine, English lecturers and subject specialists, and collected using a test (English Communication Skills for Civil Services), questionnaires, and focus group discussion (FGD), and documentations (Competency Standards of Indonesian medical Doctors known as SKDI (Standar Kompetensi Dokter Indonesia) [5] and Guideline Book for Faculty of Medicine, the University of Mataram [6]. The collected data were then analyzed using Miles \& Huberman's model of analysis consisting of data reduction, data display, and drawing conclusions [7].

With the considerations of the findings on target needs (TSA) and present situation (PSA), the recommendations of English proficiency improvement were made.

\section{Finding, Discussion, and Recommendation}

The data of needs analysis show that the target needs on learning English based on the analysis of the Competency Standard of Indonesian Medical Doctors (SKDI) and the Profile of the Faculty of Medicine are demanding. English is needed to prepare students to read academic textbooks written in English, to prepare for the TOEFL test as requirements for graduation and clinical rotation in hospital, and to prepare for job competition and professional development.

However, the high demand for English for medical students is not in line with the situations of the teaching and learning process. Various unconducive situations hinder the implementation of teaching English at the Faculty of Medicine, the University of Mataram, Lombok. Those situations are (1) the inadequate level of English (entry behavior) in which most of them are lower than intermediate as the minimum requirement to enter an ESP program [8]; (2) lack of input or exposure, in which English is a part of Block 1 - Learning Skills, is only given $3 \times 100$ minutes in the whole life of being students (even in the new curriculum it was reduced into 2 x @100 minutes); (3) the big number of students in a class, which consist $80-120$ students in a class. With those unconducive situations, it is impossible to achieve those targets.

From the target situation analysis (TSA) and the present situation analysis (PSA) mentioned above, it was found that there was a big gap between them and caused a conflict in designing language programs. The relationship between the TSA and LSA can be described in the following diagram. 


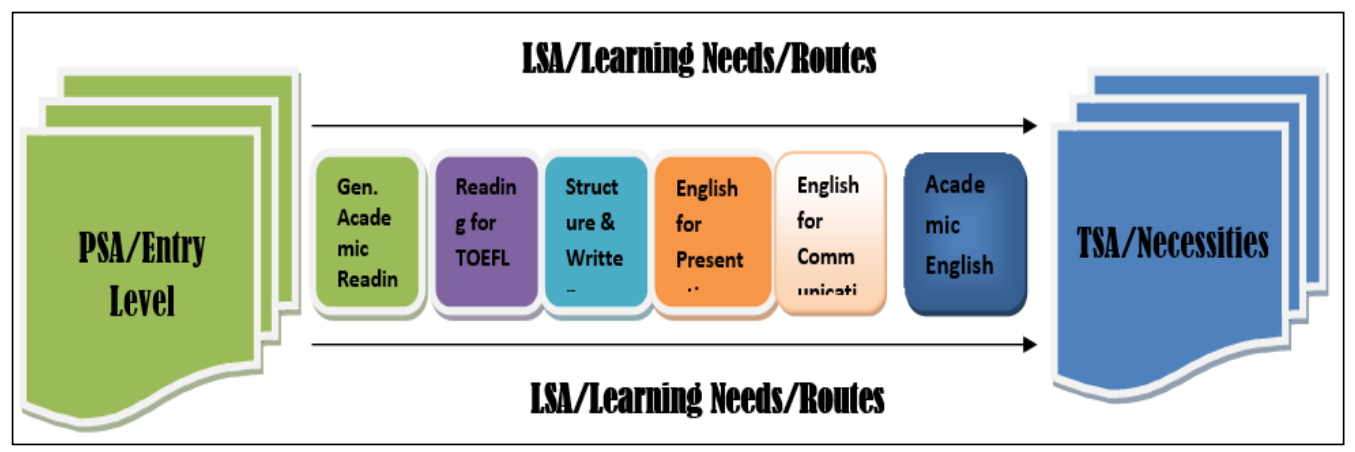

Diagram 1. The gaps between TSA and PSA

To bridge the big gap between the TSA and LSA, this research suggests a curriculum with 6 different syllabi, covering general academic reading, reading for TOEFL preparation, structure \& written expression, English for presentation, academic/content-based reading, and English for communication [9]. Those syllabi have been developed into learning materials.

However, the products developed in the present research cannot be fully used due to the amount of time allocated other obstacles in the formal class. This research, therefore, provides further recommendations as to alternative solutions to the improvement of students' English proficiency. Presented below are the recommendations for the Faculty of Medicine to take for better English proficiency.

\begin{tabular}{|c|c|c|c|c|}
\hline \multicolumn{5}{|c|}{ RECOMMUNDATIONS FOR ENGLISH IMPROVEMENT } \\
\hline $\begin{array}{l}\text { MORE INPUT FOR } \\
\text { ENGASII }\end{array}$ & $\begin{array}{l}\text { BLECTIVIV COUIRSE } \\
\text { (GH:/ESP) }\end{array}$ & BXIMIPTION POUCY & CIIL. IN BLOCK SYSTEM & $\begin{array}{l}\text { ENGHIH GLINIC } \\
\text { (OFF-/ONIINE) }\end{array}$ \\
\hline $\begin{array}{l}\text { With various } \\
\text { problems } \\
\text { mention above, it } \\
\text { is not enough } \\
\text { that English is a } \\
\text { part of Block I } \\
\text { (English is just a } \\
\text { formality: } \\
\text { It needs more } \\
\text { time to meet the } \\
\text { high demand of } \\
\text { English }\end{array}$ & $\begin{array}{l}\text { The faculty } \\
\text { needs to } \\
\text { provide } \\
\text { elective } \\
\text { courses both } \\
\text { General English } \\
\text { and ESP } \\
\text { programs to } \\
\text { solve students' } \\
\text { language } \\
\text { problems }\end{array}$ & $\begin{array}{l}\text { Needs to give } \\
\text { rewards for } \\
\text { students with } \\
\text { high levels of } \\
\text { English } \rightarrow \text { do } \\
\text { not need to take } \\
\text { English class } \\
\text { with good } \\
\text { grades } \\
\text { lt is relevant to } \\
\text { Merdeka Belajar } \\
\text { Kampus } \\
\text { Merdeka }\end{array}$ & $\begin{array}{l}\text { CLIL } \rightarrow \text { dual- } \\
\text { focused } \\
\text { education } \\
\text { (content and } \\
\text { language } \\
\text { simultaneously) } \\
\text { Taught by subject } \\
\text { specialist } \\
\text { Change of block } \\
\text { curriculum } \rightarrow \\
\text { Coyle's } 4 \text { Cs) }\end{array}$ & $\begin{array}{l}\text { needs to } \\
\text { provide offline } \\
\text { and online } \\
\text { English clinics to } \\
\text { accommodate } \\
\text { various problems } \\
\text { of English and to } \\
\text { provide self- } \\
\text { access language } \\
\text { learning (SALL) } \\
\text { materials }\end{array}$ \\
\hline
\end{tabular}

Diagram 2. Recommendation for English improvement for Faculty of Medicine 


\section{Recommendation \#1 Providing more input or exposure}

With the high demand of English for students of medicine, allocating English subject only in two 100-minute meetings during being a student at the Faculty of Medicine does not make sense. English seems only to be a "formality" program in that it is unable to make a significant contribution to English development. The Faculty needs to consider providing more input for the English subject whether it is included in other blocks system or it is as a compulsory program outside the blocks. As presented in Diagram 1 above, it is implied that the lower the students' levels of English are, the longer they need to achieve the intended goals (target needs). It is not possible to expect the students to have a good command of English with current input. Learning English needs sufficient amount of practice, thus, needs adequate time [10];[11]).

Using the curriculum and materials designed from this longitudinal study, the faculty can offer various elective programs such as general academic and academic reading, test preparations (TOEFL, IELTS), English for presentation, English for communication, etc. based on the products of this research. The students can decide which courses they want to take based on their needs and time.

\section{Recommendation \#2 Exemption Programs}

The exemption program suggested here is a program that gives a reward to students who have achieved the certain levels of English, shown with a certificate related to students' English proficiency performance in one of international standardized tests (TOEFL, IELTS, etc.). This recommendation is given based on the fact that some students have good levels of English [4]. This program will be beneficial for both students and the institution. There are some advantages of giving rewards exemption to students such as (1) it can improve beneficial washback effects, that is, the effect of the policy to future students registering to the Faculty; (2) it can reduce the number of students in an English class; (3) it can save students' time by not wasting time to learn something they have achieved. The last idea is in line with the current concept of Kampus Merdeka, Merdeka Belajar [12]. To realize this idea, it is necessary for the university and/or faculty to issue a formal regulation regarding how to implement this idea.

\section{Recommendation \#3 English Language Clinic (offline and online) and SALL}

With such unconducive situations of learning English as very limited time provided to learn English in the curriculum, students' mixed language levels, and students' lack of time to take English courses due to study workload, the recommendation to students' English improvement is by facilitating them with self-access language learning (SALL) mood and/or English clinic. With these programs, they can improve their English on their own ways, times, and purposes (autonomous learning).

To achieve those, the faculty must provide facilities and human resources to support the ideas. Utilizing the era of digital, the SALL \& English clinic can be designed in an online mood using the campus platform. The materials produced from the present research can be the basis for the online English clinic.

\section{Recommendation \#4 the application of CLIL for each Block}

If the first recommendation is hard to achieve, the subject specialists through their subjects in each block need to be involved in improving students' English proficiency. Along with English lecturers, they can approach the curriculum using Content and Language Integrated Learning (CLIL). CLIL approach is a dual-focused educational approach in which an additional 
language is used in teaching content (Coyle, Hood, \& Marsh, 2010). It is a fusion of content (subject matter) and a foreign language. CLIL is content-driven, meaning that it is taught by subject specialists, not English teachers. With high levels of English proficiency of the subject specialists at the Faculty of Medicine, University of Mataram, it is very possible to apply CLIL in Block System. What it needs is professional development to design and implement it in the block system.

The subject specialists need to be trained to integrate the components of CLIL, known as Coyle's 4Cs (Content, Communication, Cognition, and Culture), in the Block System. Content relates to the knowledge or topics being taught in the block curriculum, Communication deals with using language to learn and learning to use the target language. Cognition refers to the development of thinking skills related to the topics and language, while Culture relates to an exposure to alternative point of view and shared understanding and differences on related topics across regions or countries [13]. [The design of CLIL for faculty of medicine was presented in a different paper entitled "CLIL-ing the design of block system at the Faculty of Medicine" [14]].

Those are the possible actions that need to be taken by the Faculty of Medicine to boost students' English proficiency for their success in academic and occupation contexts. All recommendations will have their advantages and disadvantages at the levels of application.

\section{Conclusion}

We have explored the needs and the problems of English improvement at the Faculty of Medicine, the University of Mataram. There is a big gap between what needs to be achieved and the current situations of learning English at the Faculty. Although some products have been developed, they cannot be used due to the time available for English study.

It is compulsory then for the Faculty of Medicine to take further actions to improve students' English proficiency for study purposes and global competitiveness. The Faculty needs to provide more input by reconsidering the input of English through Block System or by providing elective English courses for those who need it. If those are hard to achieve due to the density of curriculum content, the Faculty can improve students' English by implementing CLIL in the block system. It needs reconstruction of the curriculum of the block. English clinic (offline and online) will be the best solution to provide materials for autonomous learning.

We would like to extend our gratitude to Kemenristekdikti and Kemdikbud for funding this research (2018-2020) and for the Faculty of Medicine, the University of Mataram Lombok for supporting the implementation of this research.

\section{References}

[1] Sujana, I. M., Fitriana, E., \& Syahrial, E. Conflicts among Aspects of Needs in Designing the Teaching of English using an ESP Approach at Higher Education in Indonesia. In M. M. Rahman, Integrating Technology and Culture: Strategies and Innovation in ELT (pp. 171-205). Jaipur , India: YKing Books; 2016. 
[2] Dafa-Allah, A.M F. ESP Learners' Needs: A case study of medicine students at some Sudanese universities. English for Specific World, 2012, 36(12), 1-16.

[3] Skelton, J. R., \& Whetstone, J. English for medical purposes and academic medicine: looking for common ground. Iberica, 2012. 24, 87-102.

[4] Sujana, I. M., Waluyo, U., Fitriana, E., \& Suryani, D. SKDI-based needs analysis for designing English for students of medicine in Indonesia. International Journal of Language Education, 2020(a), 4(2), 209-221.

[5] Konsil Kedokteran Indonesia. Standar Kompetensi Dokter Indonesia (SKDI). Jakarta: Konsil Kedokteran Indonesia; 2012.

[6] Fakultas Kedokteran. Pedoman Akademik Fakultas Kedokteran Universitas Mataram. Mataram: FK Universitas Mataram; 2016.

[7] Sugiyono. Metode penetilian kuantitatif, kualitatif, dan R \& D. Bandung: Penertbit Alfabeta; 2013

[8] Dudley-Evans, T., \& St. John, M. J.). Developments in English for Specific Purposes: A multi-disciplinary approach. Cambridge: Cambridge University Press; 1998.

[9] Sujana, I. M., Waluyo, U., Fitriana, E., \& Suryani, D.. A Curriculum and Syllabi for students of medicine (based on the Graduate Profile and SKDI). Mataram: Mataram University Press; 2019.

[10] Bahrani, T., \& Nekoueizadah, M. The role of input in second language acquisition. Journal of Advances in Linguistics, 2014, 1(1), 1-6.

[11] Renandya, W. A. The role of input- and output-based practice in ELT. In A. Ahmed, M. Hanzala, \& G. Cane, ELT in a changing world: Innovative approaches to new challenges. Newcastle: Cambridge Scholar Publishing; 2013, p. 1-12

[12] Depdikbud. Panduan Merdeka Belajar Kampus Merdeka. Jakarta: Direktorat Jenderal Pendidikan Tinggi, Kemdikbud; 2020.

[13] Coyle, D., Hood, P., \& Marsh, D. CLIL: Content and Language Integrated Learning. Cambridge: Cambridge University Press; 2010.

[14] Sujana, I. M., Waluyo, U., Fitriana, E., \& Suryani, D. CLIL-ing the design of Block System at the Faculty of Medicine, a paper presented at $2^{\text {nd }}$ ACCESS Conference, Mataram 26-26 October 2020(b). 